\title{
Disseminated histiocytoses biomarkers beyond BRAFV600E: frequent expression of PD-L1
}

\author{
Zoran Gatalica ${ }^{1}$, Nurija Bilalovic ${ }^{2}$, Juan P. Palazzo ${ }^{3}$, Ryan P. Bender ${ }^{1}$, Jeffrey \\ Swensen ${ }^{1}$, Sherri Z. Millis ${ }^{1}$, Semir Vranic ${ }^{2}$, Daniel Von Hoff ${ }^{4}$ and Robert J. Arceci ${ }^{5}$ \\ ${ }^{1}$ Caris Life Sciences, Phoenix, Arizona, USA \\ 2 Department of Pathology, Clinical Center, University of Sarajevo, Sarajevo, Bosnia and Herzegovina \\ ${ }^{3}$ Department of Pathology, Anatomy, and Cell Biology, Jefferson Medical College, Philadelphia, Pennsylvania, USA \\ ${ }^{4}$ Department of Oncology, Virginia G. Piper Cancer Center at Scottsdale Healthcare/TGen, Scottsdale, Arizona, USA \\ ${ }^{5}$ Department of Child Health, University of Arizona College of Medicine, Phoenix, Ronald Matricaria Institute of Molecular \\ Medicine at Phoenix Children's Hospital, Phoenix, Arizona, USA
}

Correspondence to: Zoran Gatalica, email: zgatalica@carisls.com

Keywords: histiocytoses, biomarkers, sequencing, targeted therapy, immunotherapy

Received: May 22, $2015 \quad$ Accepted: May 29, $2015 \quad$ Published: June 08, 2015

This is an open-access article distributed under the terms of the Creative Commons Attribution License, which permits unrestricted use, distribution, and reproduction in any medium, provided the original author and source are credited.

\section{ABSTRACT}

The histiocytoses are rare tumors characterized by the primary accumulation and tissue infiltration of histiocytes and dendritic cells. Identification of the activating BRAFV600E mutation in Erdheim-Chester disease (ECD) and Langerhans cell histiocytosis ( $\mathrm{LCH}$ ) cases provided the basis for the treatment with BRAF and/or MEK inhibitors, but additional treatment options are needed. Twenty-four cases of neoplastic histiocytic diseases [11 extrapulmonary LCH, 4 ECD, 4 extranodal RosaiDorfman disease (RDD), 3 follicular dendritic cell sarcoma (FDCS), 1 histiocytic sarcoma (HS) and 1 blastic plasmacytoid dendritic cell neoplasm (BPDCN)] were analyzed using immunohistochemical and mutational analysis in search of biomarkers for targeted therapy. BRAF V600E mutations were detected in 4/11 LCH and 4/4 ECD cases. A pathogenic PTEN gene mutation and loss of PTEN protein expression were identified in the case of HS. Increased expression of PD-L1 $(\geq 2+/ \geq 5 \%)$ was seen in $3 / 4$ ECD, 7/8 LCH, 3/3 FDCS and 1/1 HS, with overall 81\% concordance between 2 antibodies used in the study (SP142 vs. MAB1561 clone). These results show for the first time significant expression of the PD-L1 immune checkpoint protein in these disorders, which may provide rationale for addition of immune check-point inhibitors in treatment of disseminated and/or refractory histiocytoses.

\section{INTRODUCTION}

The proliferative histiocytoses encompass a broad spectrum of rare tumors with clinical behavior ranging from spontaneous regression to highly aggressive disease with fatal outcome [1]. They are characterized by the accumulation and tissue infiltration of immunologically active cells, including $\mathrm{T}$ cells, eosinophils, macrophages and dendritic cells. The histologic types include Langerhans cell histiocytosis (LCH), Rosai-Dorfman disease (RDD), Erdheim-Chester disease (ECD), follicular dendritic cell sarcoma (FDCS) and histiocytic sarcoma. In addition, blastic plasmacytoid dendritic cell neoplasm
(BPDCN) shares some characteristics with plasmacytoid monocytes (dendritic cells). Identification of the activating BRAF V600E mutation in a subset of histiocytoses (ECD and $\mathrm{LCH}, 50-100 \%$ ) has opened a new avenue for the treatment of these disorders with BRAF and MEK inhibitors [1-5]. Studies of Bubolz et al. [3] and Haroche et al. [6-7] demonstrated some efficiency of the BRAF inhibitor vemurafenib in the treatment several patients with multisystemic and refractory ECD and LCH.

The Programmed Cell Death 1 (PD-1 or CD279) protein is a T-cell co-inhibitory receptor, which upon binding of its ligand PD-L1 (CD274) expressed by tumor cells, inhibits cytokine production and cytotoxic activity of PD-1+ tumor infiltrating T-lymphocytes, facilitating tumor 
progression (escape phase of cancer immunoediting). The suppression of PD-L1/PD-1 interaction using specific inhibitors has shown promising effects in the treatment of several advanced cancers, most notably in melanoma, renal cell carcinoma and non-small cell lung cancer [8-10].

Because normal dendritic cells and macrophages express PD-L1 [11], we investigated its expression by neoplasms of dendritic and related histiocytic cell neoplasms.

\section{RESULTS}

\section{BRAF V600E and other genes' mutations}

The BRAF V600E mutation was identified in 8 out of 24 cases (33\%) including 4/4 ECD (100\%) and 4/11 LCH (36\%) while other histiocytoses harbored no BRAF V600E mutations (Table 1). One patient with BRAFV600Emutated LCH involving the parietal bone harbored additional variants of unknown significance including
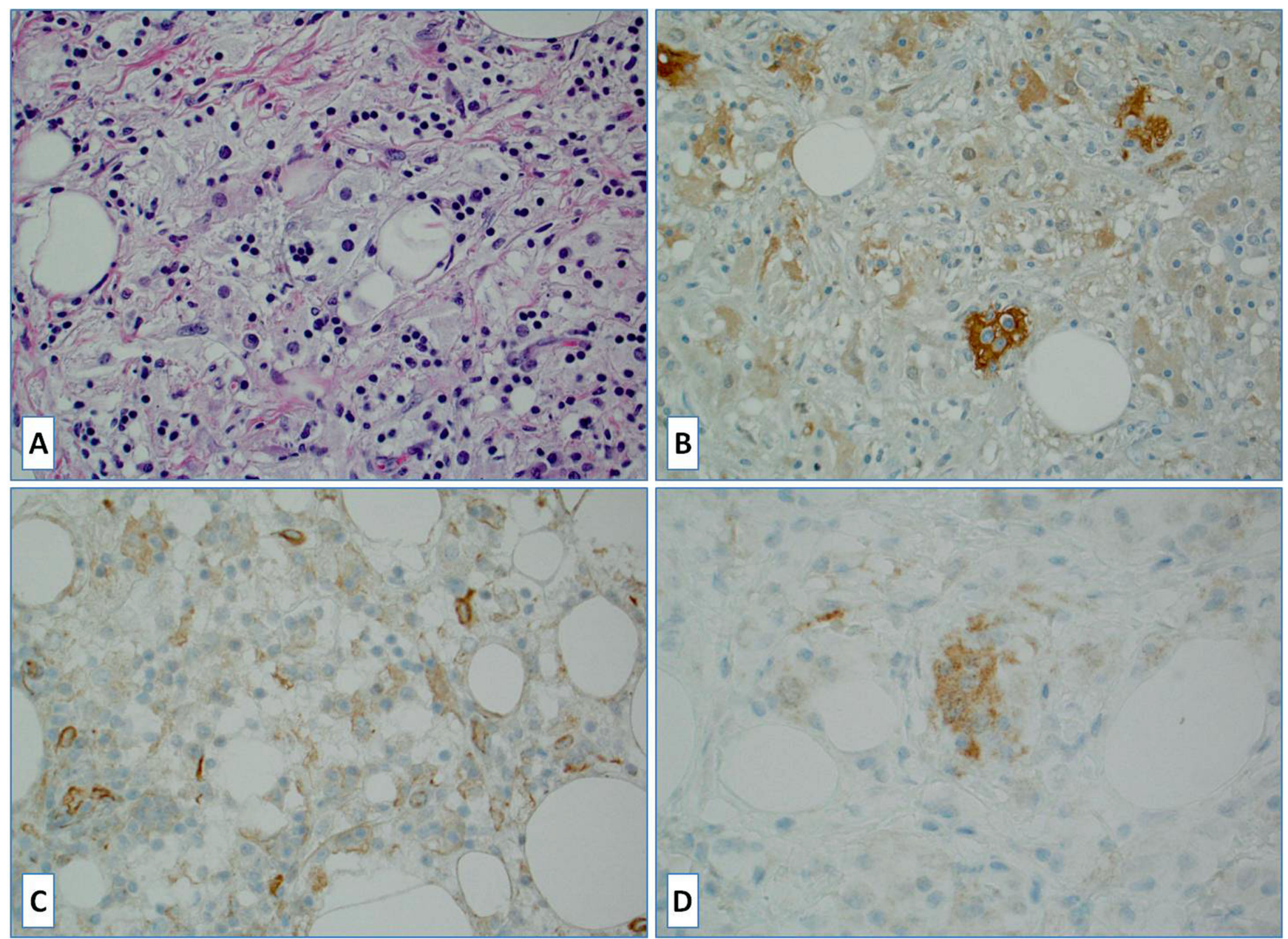

Figure 1: A case of Rosai-Dorfman disease: A. Hematoxylin and Eosin [H\&E] stained slide; B. S100 stain highlights rare diseasespecific large histiocytes with emperipolesis (negative lymphocytes within S100 positive cytoplasm); C. Lack of PD-L1 staining in large histiocytes (scattered positive reactive cells) and D. BRAFV600E scattered positive large histiocytes.
BRAF W604C, EGFR (A743V) and cMET (V378I), while another patient with BRAFV600E-mutated LCH had a $J A K 3$ (V722I) mutation. The BRAF V600E mutant protein was detected in 3 out of 5 BRAF V600E mutated cases $(60 \%)$ using immunohistochemistry (Figures 2D, 3C, 4B, and 4D) while the single BRAFV600E-sequencingnegative RDD case stained positively for BRAFV600E protein (Figure 1D). A case of HS that was devoid of mutation (c.635-7 639del; a splice site mutation that abolishes the conserved splice region at exon 7 of PTEN gene) confirmed by the loss of PTEN protein by IHC (Figure 2C). A variant of unknown significance involving SMAD4 (T521I mutation) was detected in a patient with BRAF-negative extranodal RDD.

\section{PD-1 and PD-L1 expression}

Overexpression of PD-L1 $(\geq 2+/ \geq 5 \%)$ was seen in the majority of cases (3/4 ECD, 7/8 LCH, 3/3 FDCS and 1/1 HS, Table 1, Figures 1C, 2B, 3B, 4A, and 4C), but a BRAF V600E mutation harbored pathogenic, PTEN 
Table 1: Overview of BRAF, other mutations and PD-L1 status in various neoplastic histiocytoses

\begin{tabular}{|c|c|c|c|}
\hline $\begin{array}{c}\text { Histotype } \\
(\mathrm{n}=24)\end{array}$ & $\begin{array}{c}B R A F^{V 600 E} \\
(\% \#)\end{array}$ & $\begin{array}{l}\text { PD-L1 } \\
\text { expression* }\end{array}$ & Other mutations \\
\hline Langerhans $\underset{(\mathrm{n}=11)}{\text { cell }}$ histiocytosis & $36 \%$ & $88 \%$ & \begin{tabular}{|lr} 
cMET, & EGFR, \\
W604C & BRAF \\
case $)^{* *}$ \\
JAK3 $(1 \text { case })^{* *}$
\end{tabular} \\
\hline $\begin{array}{c}\text { Rosai-Dorfman disease } \\
(\mathrm{n}=4)\end{array}$ & $0 \%{ }^{\# \#}$ & $0 \%$ & SMAD4 (1 case)*** \\
\hline $\begin{array}{l}\text { Erdheim-Chester disease } \\
(\mathrm{n}=4)\end{array}$ & $100 \%$ & $100 \%$ & None \\
\hline $\begin{array}{c}\text { Follicular dendritic cell sarcoma } \\
(\mathrm{n}=3)\end{array}$ & $0 \%$ & $100 \%$ & None \\
\hline $\begin{array}{l}\text { Histiocytic sarcoma } \\
(\mathrm{n}=1)\end{array}$ & $0 \%$ & $100 \%$ & PTEN \\
\hline $\begin{array}{c}\text { Blastic plasmacytoid dendritic cell } \\
\text { neoplasm }(\mathrm{n}=1)\end{array}$ & $0 \%$ & $0 \%$ & None \\
\hline
\end{tabular}

* 81\% concordance was obtained between MAB1561 and SP142 antibodies.

** Both LCH cases also harbored BRAF V600E mutation. All described mutations represent variants of unknown significance.

$* * *$ Variant of unknown significance.

\# Using COBAS method

\#\# A single case of RDD which was negative for detection of mutations in BRAF (Both Cobas and NGS) was positive using IHC for mutated BRAF V600E protein.
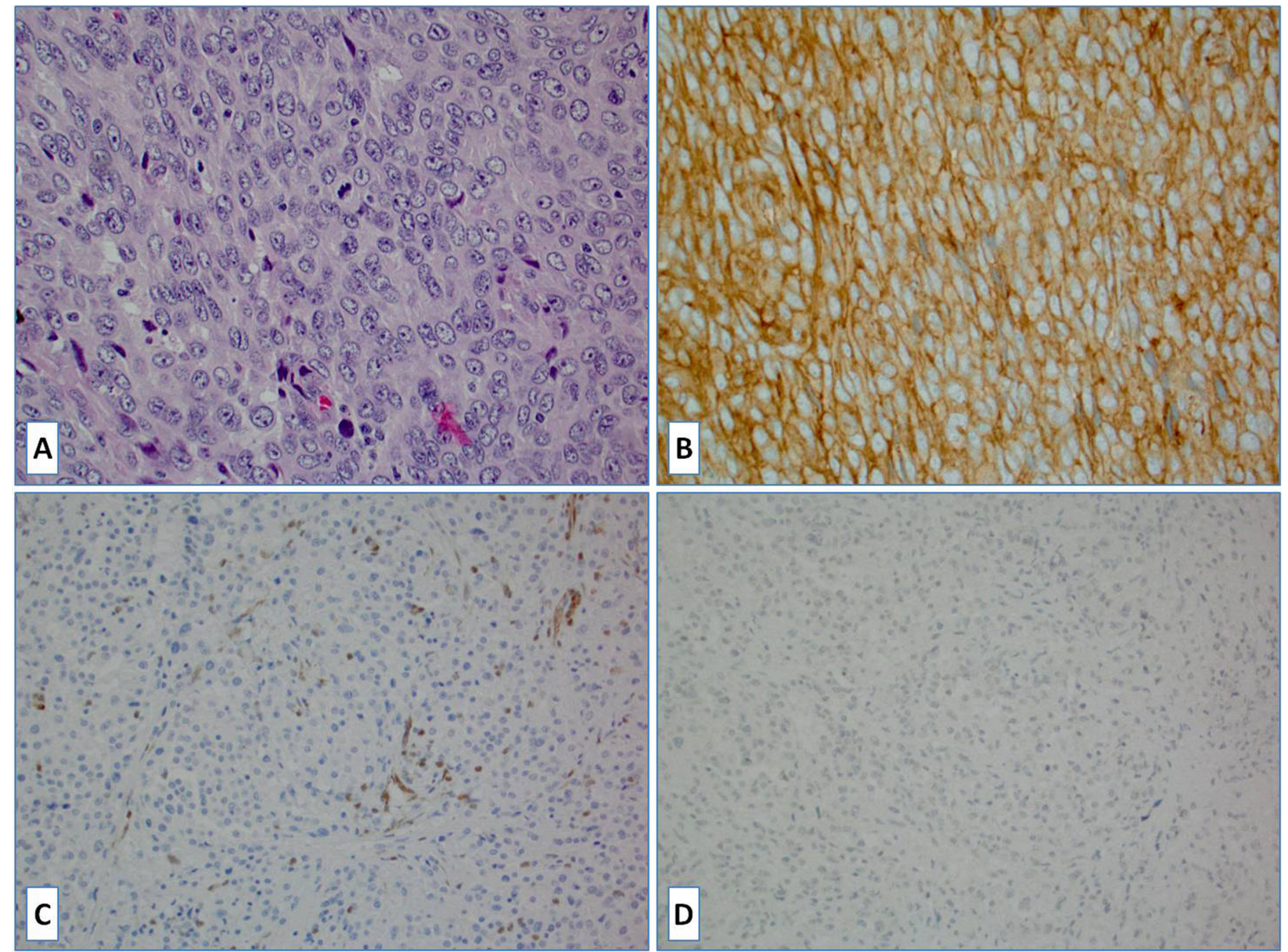

Figure 2: A. H\&E slide of a case of histiocytic sarcoma; B. The tumor cells were strongly positive for PD-L1; C. The tumor completely lost PTEN protein expression due to the PTEN gene mutation (normal PTEN expression is seen in endothelium); D. No BRAFV600E mutant protein expression was observed. 


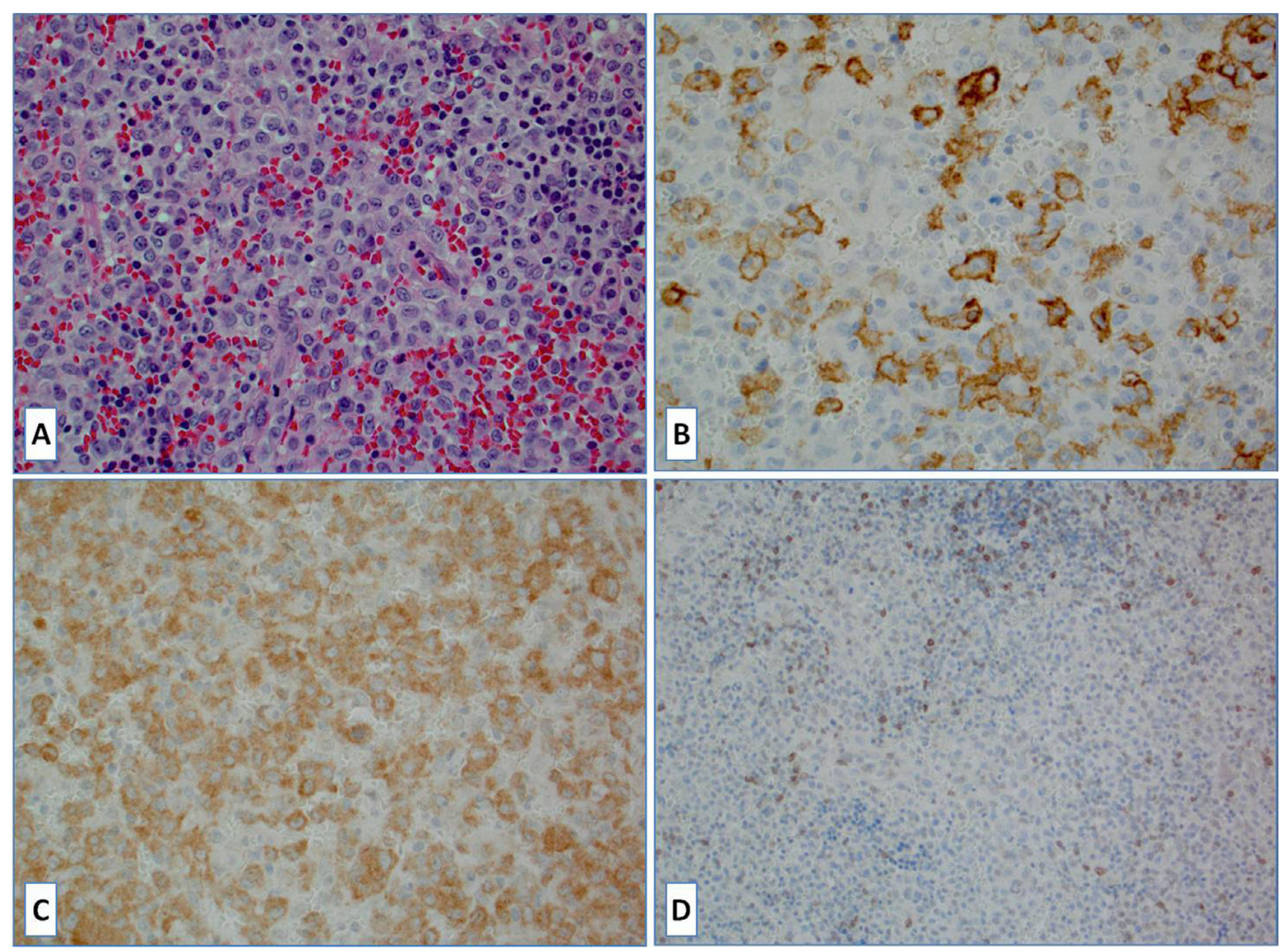

Figure 3: A. Langerhans cell histiocytosis (LCH), H\&E slide; B. Large neoplastic Langerhans cells are strongly positive for PD-L1; C. BRAFV600E mutant protein expression (BRAF gene mutation confirmed) D. Tumor-infiltrating lymphocytes were positive for PD-1.
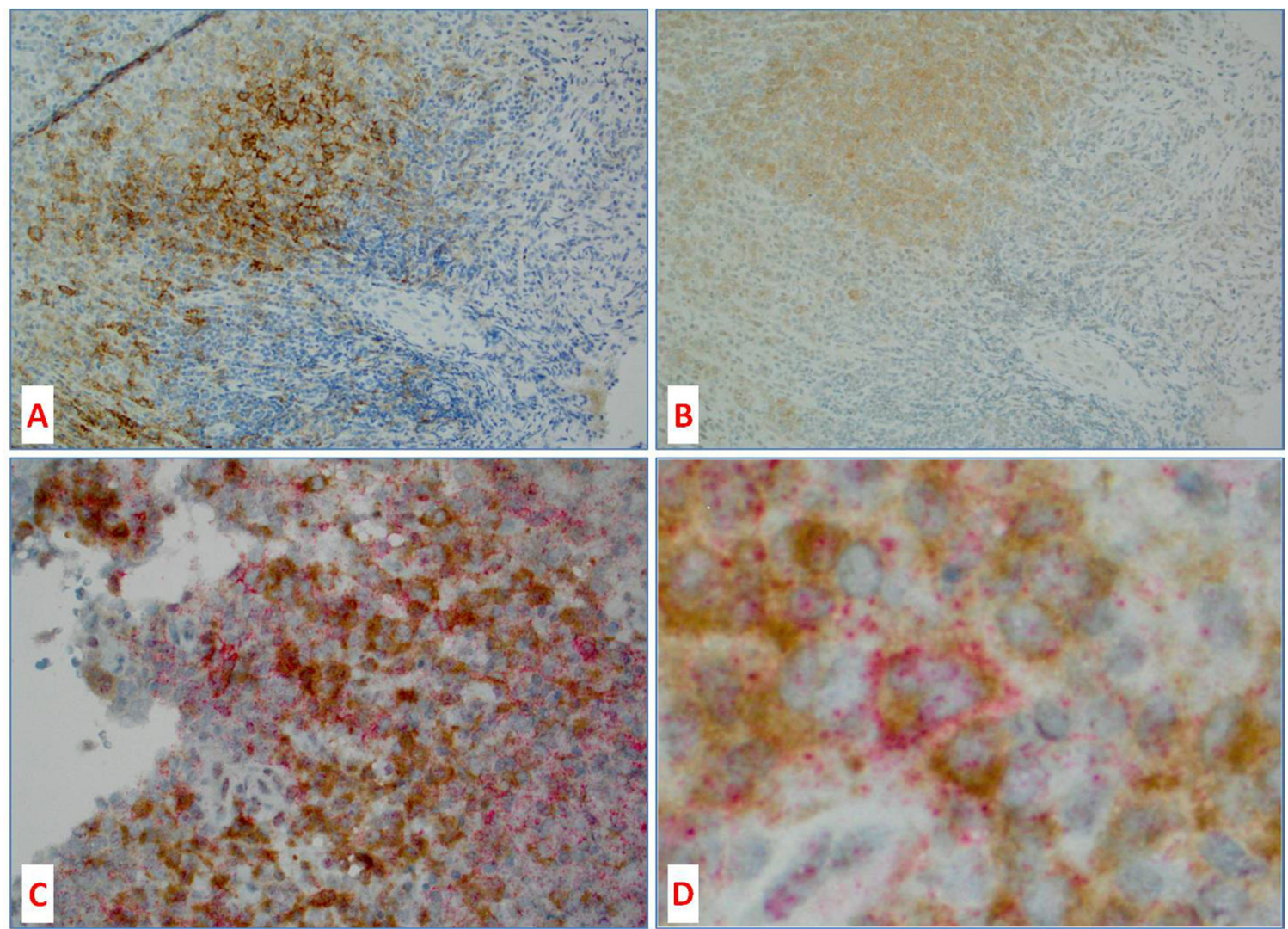

Figure 4: Co-localization of BRAFV600E protein and PD-L1 in histiocytic tumors. A. PD-L1 and B. BRAFV600 mutant protein expression in 2 consecutive sections (8 microns apart) showing similar topographic distribution of PD-L1 and BRAFV600E; C. and D. are double IHC for PD-L1 (red) and BRAFV600E (brown) showing co-localization of both stains to the same Langerhans cell (D - center). 
not in RDD and BPDCN. The expression of PD-L1 in neoplastic cells was appreciatively stronger $(2+$ and $3+$ staining intensity) than in normal macrophages or dendritic cells present at the periphery of the lesions $(1+)$. We found overall $81 \%$ concordance between two antibodies directed against PD-L1 (SP142 and MAB1561 clones). The highest concordance rate was seen in RDD (100\%) and LCH (89\%) while MAB1561 antibody appeared to be more sensitive in detection of positive cells in ECD (3+/3, $100 \%$ ) than SP142 antibody that was positive in only 1 out of 4 tested cases $(25 \%)$.

Figures 3 and 4 illustrate a case of $\mathrm{LCH}$ with BRAFV600E mutation expressing PD-L1 in neoplastic Langerhans cells, which in the consecutive sections show co-localization of BRAFV600E and PD-L1 positive cells. Double immunohistochemical stain also showed both PDL1 (red) and BRAFV600E (brown) proteins co-localizing to the same multinucleated Langerhans cell.

PD-1 expressing tumor infiltrating lymphocytes were variably present in all the disease subtypes (Figure 3D).

\section{DISCUSSION}

The histiocytoses are rare neoplasms with highly unpredictable clinical course ranging from spontaneous regression to highly aggressive disease with fatal outcome [1]. In the present study we explored the expression of the key checkpoint molecules, PD-1 and PD-L1, in these disorders along with the detection of gene mutations. The mutational analyses confirmed overall low number of mutated genes in histiocytoses $[2,15]$ with the pathogenic $B R A F$ V600E mutations characterizing the majority of LCH and ECD [1-5]. These data support the rationale for the use of therapy targeting BRAF and/or MEK1 inhibitors for selected refractory and multisystem histiocytoses [3, 5-7]. Mutations have also been reported involving reported KRAS, NRAS and PIK3CA mutations in BRAF V600E -negative ECD $[5,16,17]$. We also found several additional mutations/variants of unknown significance (e.g. $c M E T, E G F R$ ).

Although Go et al. [18] reported a high frequency of $B R A F$ V600E mutations in histiocytic sarcomas, a single case in our series harbored no BRAF V600E; instead a pathogenic PTEN mutation followed by PTEN protein loss was detected. Carrasco et al. reported partial and complete PTEN gene deletions with concomitant loss of PTEN expression in 2 of 6 HS cases [19].

Our study for the first time demonstrates that PDL1 frequently shows high levels of expression in systemic histiocytoses. PD-1 represents an immunosuppressive molecule whose expression on T-lymphocytes and other immune cells is an important part of immune surveillance. Activation by the ligand (PD-L1) results in attenuation of the immune response [9]. The ligand (PD-L1) may be aberrantly expressed on the neoplastic cells or on the immune cells at the tumor/host interface, and therapypredictive contribution of either of the components still needs to be determined [8]. Inhibition of the PD-1/PD-L1 axis has been shown to be a promising therapeutic target in various cancers, particularly in renal cell carcinoma, nonsmall cell lung carcinoma and malignant melanoma [8-10]. We and others also reported on the expression of PD-L1 in a variety of both solid and hematological malignancies [8, 12, 20-22], but not yet in neoplastic histiocytic diseases. A study conducted by Muenst et al. [23] reported PD-1 expression in a single case of RDD. Our data indicate that a subset of histiocytoses, including LCH, ECD, FDCS, and HS, may be potentially amenable to the targeted therapy with immune checkpoint inhibitors based on the high levels of expression of these check-point molecules. This might be particularly relevant for the subset of systemic histiocytoses that are refractory to conventional and/or targeted therapies. The results also suggest the possibility of combining targeted small molecule targeted agents with PD-1/PD-L1 inhibitors. We used two different antibodies against PD-L1 to explore their diagnostic utility. Our results indicate a good concordance $(81 \%)$ between the two antibodies with the MAB1561 antibody being a more sensitive than SP142 antibody. Future studies are needed to test the predictive value and utility of PD-L1 antibodies and immunohistochemistry as a method for directing targeted PD-1/PD-L1 therapy (i.e., companion diagnostic testing).

Our results of the high level of expression of PD-L1 expression in histiocytoses, along with the frequent $B R A F$ and other ERK pathway gene mutations provide additional support for testing combination therapeutic approaches for patients with multisystem and/or refractory forms of histiocytoses.

\section{MATERIALS AND METHODS}

\section{Samples and patients}

The study included 24 patients (14 males and 10 females; age range, 2-74 years, mean: 42 years) diagnosed with histiocytic diseases including 4 cases of extranodal RDD, $11 \mathrm{LCH}$ (10 extra pulmonary and 1 pulmonary), 4 ECD (2 retroperitoneal soft tissue and 2 involving cranial bones), 3 follicular dendritic cell sarcomas (FDCS, involving thorax and colon, respectively), $1 \mathrm{HS}$ (bone) and 1 blastic plasmacytoid dendritic cell neoplasm (BPDCN, skin). All samples were reviewed by a board-certified pathologist (Z.G.) to confirm the diagnosis. All testing had been performed in Caris Life Sciences (Phoenix, Arizona) facility which is CLIA certified and CAP, ISO and NYSDOH accredited. 


\section{Immunohistochemistry (IHC)}

Formalin-fixed paraffin-embedded (FFPE) tissue sections were stained for PD-L1 [clones: anti-human PDL1 rabbit monoclonal antibody SP142, Spring Bioscience; and anti-human MAB1561 mouse monoclonal antibody, R\&D Systems] and PD-1 (monoclonal antibody NAT105, Cell Marque). The tumor sample was considered positive for PD-L1 if 2+ intensity (complete membranous staining) was observed in $\geq 5 \%$ of cells [8]. Any extent of the presence of $\mathrm{PD}-1+$ tumor infiltrating lymphocytes was considered positive [12]. BRAFV600E mutant protein was detected using VE1 antibody (mouse monoclonal antibody, Ventana Medical Systems, Tucson, AZ) [13, 14]. PTEN expression was analyzed using monoclonal $6 \mathrm{H} 2.1$ antibody (Dako, Carpinteria, CA). Selected cases were stained using double immunohistochemical staining (Figure 4) with diaminobenzidine tetra hydrochloride (DAB) as a brown chromogen for horseradish peroxidase and Naphtol and Fast red chromogen for alkaline phosphatase. Additional immunohistochemical tests were performed to confirm the diagnosis and to highlight the pathogenic cell population (e.g. S-100, CD68, CD1a detection).

\section{Mutational analysis}

\section{Next-generation sequencing (NGS)}

Direct sequencing analysis was performed on genomic DNA isolated from FFPE samples using the Illumina MiSeq platform. Specific regions of the genome were amplified using the Illumina TruSeq Amplicon Cancer Hotspot panel. The panel included 46 genes sequenced by NGS and can be found at: http:// www.carismolecularintelligence.com/next-generationsequencing-profile. All variants reported by NGS are detected with $>99 \%$ confidence based on the frequency of the mutation present and the amplicon coverage using a mutation frequency threshold of $10 \%$. All regions that are sequenced achieve a minimum of $100 \mathrm{x}$ coverage and overall samples have an average coverage of $>500 x$.

\section{Cobas BRAF V600E analysis}

$B R A F$ mutation analysis was done using the Cobas ${ }^{\circledR}$ 4800 BRAF V600 Mutation Test (Roche Diagnostics). DNA was isolated from the FFPE tumor samples using standard laboratory procedures. Real-time PCR was used to amplify the exon 15 of the BRAF gene. Following amplification, a set of differentially labeled fluorescent probes were utilized to detect normal and mutant V600 sequences.

\section{ACKNOWLEDGMENTS}

Preliminary data from the study were reported at the 2015 ASCO Annual Meeting, May 29 - June 2, 2015, Chicago, IL.

\section{CONFLICTS OF INTEREST}

D. Von Hoff had ownership interest in and is a consultant to Caris Life Sciences and advisor to BristolMyers Squibb. R.J. Arceci is consultant/advisory board member to Pfizer. S. Vranic is a consultant for Caris Life Sciences. Z. Gatalica, R.P. Bender, J. Swensen, and S.Z. Millis are employees of Caris Life Sciences. N. Bilalovic and J.P. Palazzo declare no conflict of interest.

\section{Editorial note}

This paper has been accepted based in part on peerreview conducted by another journal and the authors' response and revisions as well as expedited peer-review in Oncotarget.

\section{REFERENCES}

1. Arceci RJ. Biological and therapeutic implication of the BRAF pathway in histiocytic disorders. Am Soc Clin Oncol Educ Book. 2014:e441-445.

2. Badalian-Very G, Vergilio JA, Degar BA, MacConaill LE, Brandner B, Calicchio ML, Kuo FC, Ligon AH, Stevenson KE, Kehoe SM, Garraway LA, Hahn WC, Meyerson $\mathrm{M}$, et al. Recurrent BRAF mutations in Langerhans cell histiocytosis. Blood. 2010; 116:1919-1923.

3. Bubolz AM, Weissinger SE, Stenzinger A, Arndt A, Steinestel K, Brüderlein S, Cario H, Lubatschofski A, Welke C, Anagnostopoulos I, Barth TF, Beer AJ, Möller P, et al. Potential clinical implications of BRAF mutations in histiocytic proliferations. Oncotarget. 2014; 5:4060-4070.

4. Haroche J, Charlotte F, Arnaud L, von Deimling A, HéliasRodzewicz Z, Hervier B, Cohen-Aubart F, Launay D, Lesot A, Mokhtari K, Canioni D, Galmiche L, Rose C, et al. High prevalence of BRAF V600E mutations in Erdheim-Chester disease but not in other non-Langerhans cell histiocytoses. Blood. 2012; 120:2700-2703.

5. Hyman DM, Diamond EL, Vibat CR, Hassaine L, Poole JC, Patel M, Holley VR, Cabrilo G, Lu TT, Arcila ME, Chung YR, Rampal R, Lacouture ME, et al. Prospective blinded study of BRAFV600E mutation detection in cellfree DNA of patients with systemic histiocytic disorders. Cancer Discov. 2015; 5:64-71.

6. Haroche J, Cohen-Aubart F, Emile JF, Maksud P, Drier A, Tolédano D, Barete S, Charlotte F, Cluzel P, Donadieu J, Benameur N, Grenier PA, Besnard S, et al. Reproducible and Sustained Efficacy of Targeted Therapy With Vemurafenib in Patients With BRAFV600E-Mutated Erdheim-Chester Disease. J Clin Oncol. 2015; 33:411-418.

7. Haroche J, Cohen-Aubart F, Emile JF, Arnaud L, Maksud 
P, Charlotte F, Cluzel P, Drier A, Hervier B, Benameur N, Besnard S, Donadieu J, Amoura Z. Dramatic efficacy of vemurafenib in both multisystemic and refractory ErdheimChester disease and Langerhans cell histiocytosis harboring the BRAF V600E mutation. Blood. 2013; 121:1495-1500.

8. Herbst RS, Soria JC, Kowanetz M, Fine GD, Hamid O, Gordon MS, Sosman JA, McDermott DF, Powderly JD, Gettinger SN, Kohrt HE, Horn L, Lawrence DP, et al. Predictive correlates of response to the anti-PD-L1 antibody MPDL3280A in cancer patients. Nature. 2014; 515:563567.

9. Taube JM, Klein A, Brahmer JR, Xu H, Pan X, Kim JH, Chen L, Pardoll DM, Topalian SL, Anders RA. Association of PD-1, PD-1 ligands, and other features of the tumor immune microenvironment with response to anti-PD-1 therapy. Clin Cancer Res. 2014; 20:5064-5074.

10. Topalian SL, Hodi FS, Brahmer JR, Gettinger SN, Smith DC, McDermott DF, Powderly JD, Carvajal RD, Sosman JA, Atkins MB, Leming PD, Spigel DR, Antonia SJ, et al. Safety, activity, and immune correlates of anti-PD-1 antibody in cancer. N Engl J Med. 2012; 366:2443-2454.

11. Keir ME, Francisco LM, Sharpe AH. PD-1 and its ligands in T-cell immunity. Curr Opin Immunol. 2007; 19:309-314.

12. Gatalica Z, Snyder C, Maney T, Ghazalpour A, Holterman DA, Xiao N, Overberg P, Rose I, Basu GD, Vranic S, Lynch HT, Von Hoff DD, Hamid O. Programmed cell death 1 (PD-1) and its ligand (PD-L1) in common cancers and their correlation with molecular cancer type. Cancer Epidemiol Biomarkers Prev. 2014; 23:2965-2970.

13. Ritterhouse LL, Barletta JA. BRAF V600E mutationspecific antibody: A review. Semin Diagn Pathol. 2015 Feb 7. pii: S0740-2570(15)00011-8. doi: 10.1053/j. semdp.2015.02.010. [Epub ahead of print]

14. Kuan SF, Navina S, Cressman KL, Pai RK. Immunohistochemical detection of BRAF V600E mutant protein using the VE1 antibody in colorectal carcinoma is highly concordant with molecular testing but requires rigorous antibody optimization. Hum Pathol 2014; 45:464472.

15. Chakraborty R, Hampton OA, Shen X, Simko SJ, Shih A, Abhyankar H, Lim KP, Covington KR, Trevino L, Dewal $\mathrm{N}$, Muzny DM, Doddapaneni $\mathrm{H}, \mathrm{Hu}$ J, et al. Mutually exclusive recurrent somatic mutations in MAP2K1 and BRAF support a central role for ERK activation in LCH pathogenesis. Blood. 2014; 124:3007-3015.

16. Diamond EL, Abdel-Wahab O, Pentsova E, Borsu L, Chiu A, Teruya-Feldstein J, Hyman DM, Rosenblum M. Detection of an NRAS mutation in Erdheim-Chester disease. Blood. 2013; 122:1089-1091.

17. Emile JF, Diamond EL, Hélias-Rodzewicz Z, CohenAubart F, Charlotte F, Hyman DM, Kim E, Rampal R, Patel M, Ganzel C, Aumann S, Faucher G, Le Gall C, et al. Recurrent RAS and PIK3CA mutations in Erdheim-Chester disease. Blood. 2014; 124:3016-3019.
18. Go H, Jeon YK, Huh J, Choi SJ, Choi YD, Cha HJ, Kim HJ, Park G, Min S, Kim JE. Frequent detection of BRAF(V600E) mutations in histiocytic and dendritic cell neoplasms. Histopathology. 2014; 65:261-272.

19. Carrasco DR, Fenton T, Sukhdeo K, Protopopova M, Enos M, You MJ, Di Vizio D, Nogueira C, Stommel J, Pinkus GS, Fletcher C, Hornick JL, Cavenee WK, et al. The PTEN and INK4A/ARF tumor suppressors maintain myelolymphoid homeostasis and cooperate to constrain histiocytic sarcoma development in humans. Cancer Cell. 2006; 9:379-390.

20. Gatalica Z, Millis SZ, Vranic S, Bender R, Basu GD, Voss A, Von Hoff DD. Comprehensive tumor profiling identifies numerous biomarkers of drug response in cancers of unknown primary site: Analysis of 1806 cases. Oncotarget. 2014; 5:12440-12447.

21. Ansell SM, Lesokhin AM, Borrello I, Halwani A, Scott EC, Gutierrez M, Schuster SJ, Millenson MM, Cattry D, Freeman GJ, Rodig SJ, Chapuy B, Ligon AH, et al. PD-1 blockade with nivolumab in relapsed or refractory Hodgkin's lymphoma. N Engl J Med. 2015; 372:311-319.

22. Chen BJ, Chapuy B, Ouyang J, Sun HH, Roemer MG, Xu ML, Yu H, Fletcher CD, Freeman GJ, Shipp MA, Rodig SJ. PD-L1 expression is characteristic of a subset of aggressive B-cell lymphomas and virus-associated malignancies. Clin Cancer Res. 2013; 19:3462-3473.

23. Muenst S, Dirnhofer S, Tzankov A. Distribution of PD-1+ lymphocytes in reactive lymphadenopathies. Pathobiology. 2010; 77:24-27. 